\title{
NEIS OF THE ASSOCIATION
}

\section{statement of MESA on the Future of Federal Support for Foreign Area Studies}

In response to the request of the President's Commission on Foreign Language and International Studies for a statement of the Association's position on federal support for international studies, MESA, in cosponsorship with the Aspen Institute,. held a small conference on the subject, "Middle East Studies: The Next Twenty Years." The conference took place in Tarrytown, N.Y., on March 23-24, 1979. Fifteen of the 29 attendees were from the scholarly community and represented most of the centers of Middle East studies. The rest included businessmen, foundation, representatives and individuals concerned with the federal government's role in international studies.

The two days of discussions were divided into topics relating to current and future problems and topics relating to future funding sources. The former included presentations on the news media, business concerns with Middle East studies, Library and publishing problems, outreach efforts, undergraduate curriculum, and federal government utilization of Middle East specialists. The latter covered foundation funding, business corporation funding, and federal funding.

Against the background of the discussions at the Tarrytown Conference, I prepared a statement on behalf of the Association and submitted it to the President's Commission. I subsequently collaborated in the preparation of an additional statement submitted to the Commission as the collective position of all of the major regional studies associations. The texts of these two statements follow (dated 4-9-1979).

Richard w. Bulliet

Executive Secretary

Events of the past year in the Middle East have served to highlight the urgency of our national problem in the field of foreign area sturies. Various opinions have been advanced as to the success or failure of our government's policy in that crucial part of the world, but these opinions do not speak to the issue of foreign area education. What does speak, and speak most urgently and most incontrovertibly, is the too-abundant evidence of ignorance, incomprehension, and even intolerance in the presence of the American public to events in the Middle East. That bias and ignorance about the Middle East have been the diet of American students in the lower grades has been well establish ed, " but news media responses and public attitudes in recent months have now clearly demonstrated that an ill-informed population in an increasingly interdependent world can jeopardize the national welfare. Moreover, today's misinformed overreactions to Islamic revolution or Arab energy policy could as easily recur tomorrow with regard to events in Latin America, Africa, or South Asia. In short, the problem of educating the public for informed citizenship in the world community is urgent and immediate. Failure to confront this problem effectively could be injurious to our national interest in the short term

"See, for example, Michael W. Suleiman, American Images of MiddZe East Peoples: Impact of the High School. New York: Middle East Studies Association, 1977. 
and disastrous in the longer run.

Any approach to facing this urgent problem has to start with certain given facts. One of these is that the community of scholars capable of producing reliable analysis and well-documented study of other regions of the world is, for most foreign areas, quite small, numbering one or two thousand, clustered mainly in a handful of universities with heavy commitments to foreign-area studies. A second fact is that this limited body of specialized scholars, although facing a shrinkage of employment opportunities with the overall contraction of higher education, is far from underutilized. The achievement of the last quarter century of foreign-area study in the production of schoLarly research and trained specialists is too well documented to need repeating. Existing programs of this sort not only warrant continued support by virtue of their proven worth, but absolutely require it by virtue of their direct relation to the national interest. Much of our foreign policy and private foreign involvement at the present day is based either directly or indirectly upon the work of the last two generations of scholarship in international studies. Yet neither the world-at-large nor the world of scholarship remains immutable; research and publication for understanding tomorrow's international problems must be done today, just as tomorrow's foreign-area specialists must begin their training today. These have been the prime missions of foreign-area studies in the past, and they will continue to be prime missions in the future.

What, then, of the urgent problem in the realm of educating the American public-at-large? How can this small segment of the academic community address itself effectively to the needs of precollegiate education and citizens" education without sacrificing continued fulfillment of long-established and vital missions?

A mistaken approach would be to interpret the contracting academic employment situation for foreign-area specialists as evidence that the teaching and research pursuits which have received greatest emphasis in the past, have accomplished their goals and that it is, therefore, time to shift the emphasis in international education away from train ing specialists. The causes of the shrinking academic job market are well known and entirely unrelated to the valid concerns that prompted federal support for foreign-area education in the first place. Even if there were no employment opportunities at all in higher education for Ph.D.S with a Middle East specialization, there would still be a manifest national need for people who had truly expert knowledge of that part of the world. Therefore, a diversion of effort cannot be justified by this line of reasoning.

Scholarly research and specialist training must be maintained at at least their current levels, and the federal contribution to the maintenance of these programs is crucial, since it is symbolic of national commitment global realities and, therefore, encourages universities and outside funding sources to continue their support.

The same holds true with equal force when it comes to supporting foreign language collections in research libraries, language study programs abroad, and American scholarly research institutes located in foreign countries.

Over the last few years a partial redirection of emphasis in federal support has been attempted through the OUTREACH PROGRAMS of the federally funded regional studies centers. The motivation behind these 
programs has been laudable, but from the start existing legislation constrained consideration of the optimum way of achieving the desired ends. To date, the number of flourishing Outreach Programs is small, although the movement is still gaining headway. Yet, it might well be asked whether working through regional studies centers is a cost-effective way of accomplishing the goal of disseminating foreign-area expertise among the broader public. Few faculty members have shown a real commitment to the programs; the geographical distribution of centers is not particularly well suited to the task; competition among centers for federal funding inhibits sharing of information about outreach that might give an edge to a competing institution; and some jobs, such as preparation of precollegiate and undergraduate teaching materials, would be better accomplished on a national basis and disseminated by national organizations such as the scholarly regional studies associations.* In short, there is good reason to reconsider this aspect of the federal effort in international education and devote the $10-15 \%$ of center funds allocated to this function to their other, more centered tasks.

\section{A Proposal}

As a specific program that would go far toward meeting the goals represented by the Outreach concept, while reinforcing instead of jeopardizing the existing research and specialist training aspect of foreign-area education, we suggest the following:

The Office of Education should make avajlable to institutions of higher learning (including community colleges), which do not currently have on their faculty a qualified specialist in a non-Western culture, $50 \%$ funding of the salary of such a specialist at a beginning faculty level for a non-renewable period of five (5) years. Institutions would apply for a subsized foreign-area faculty member, with the understanding that the other half of the salary would be borne by the institution itself, and that half the faculty member's teaching load could be unrelated to his or her foreign-area specialization. Geographical distribution would be mandated to ensure that all parts of the country would become recipients of such foreign-area specialists. Competition for subsidized specialists among institutions in a single area would ensure the planned integration of such a faculty member into the permanent staff and curriculum of the applying institution.

From the point of view of Outreach and citizens' education, a Program of this nature would guarantee the implanting of genuine foreign area expertise in educational institutions currently devoid of such expertise, and it would do this for a sufficiently long period of time to have genuine educational benefits. Instead of depending upon the haphazard geographical distribution of area studies centers, the concentration or distribution of foreign-area specialists could be easily altered to fit changing demands. The foreign-area specialists selected for this Program would be informed that a part of their job would be to serve as community resource persons, and a small sum of money would be earmarked for each person to expend for this purpose.

From the point of view of the established university programs in

*Currently a large NEH grant is supporting a national committee engaged in the preparation of undergraduate teaching materials dealing with Islam and the Middle East. 
area studies, this new Program would enhance their ability to attract and train students and thus to maintain the vital national pool of foreign-area specialists. It would do this by significantly increasing the number of job opportunities in the field of higher education. Although the five-year jobs would be entry level only, the proven effectiveness of federal money in stimulating other sorts of funding would make it more than likely that some of the jobs would be taken over and fully funded by the institution in question at the end of the five-year period, thus permanently implanting a commitment to foreign area studies in a previously uncommitted institution. Because of its potential for opening up new job opportunities, this Program could be expected to find broad cooperation and encouragement within the existing area or international studies programs, or basic department structures.

The cost of this Program would not be particularly great. Eighty openings per year (that is, an average of one per area studies center) should cost less than $\$ 1$ million in the first year; this would rise in the subsequent years because of the five-year term of the appointment. A small part of the funds might be devoted to ensuring continuing contact between these dispersed foreign-area specialists and their professional colleagues in order to reduce the feeling of isolation that might otherwise develop.

It should be noted that the cost of this Program would not be substantially greater than the cost of the current Outreach Programs, but the funds would be expended directly upon well-trained specialists in stead of part-time and sometimes poorly qualified coordinators and assistants, the Outreach benefits would be distributed nationally in a more equitable and controllable manner, and the established area studies faculties would be fully supportive instead of uncooperative, and even hostile, as many are toward current efforts.

To summarize the advantages of the proposed Outreach Program:

1. Increased employment opportunities would enable vital research and training programs already in place to continue to recruit and educate foreign-area specialists.

2. Foreign-area expertise would be implanted in institutions and communities where it does not currently exist, with some implantations probabily becoming permanent.

3. Outreach functions would be performed locally from an abundance of new locations scattered throughout the country. They would no longer be dependent upon area studies centers. The federal salary support would guarantee earnest effort being put into these functions by the job recipients.

4. In the long run, with a quite limited financial commitment, an informed awareness of foreign areas would be disseminated throughout the country, with predictable benefits in terms of improved public understanding of the world community and our own place within it.

\section{President's Commission on Foreign Language and International Studies}

Statement of International and Area Studies Organizations

The President's Commission on Foreign Language and International Studies is requested to consider the following principles relating to 